\title{
Opening the oyster: the 2010-11 NHS reforms in England
}

\author{
Lucy Reynolds and Martin McKee
}

\begin{abstract}
This opinion paper briefly considers the credibility of the announced rationale behind the current extensive reform of the NHS in light of recent research evidence about performance of the system. The paper outlines the authors' views of the history of the reform, which originates in a set of documents, produced in the late 1980s by the Centre for Policy Studies, which aimed to introduce private sector involvement throughout the NHS, and a brief report by a consultant for a health maintenance organisation in the USA. Tracking of the pro-private sector changes in the NHS demonstrates that the bill is a major step in the implementation of NHS privatisation and also delineates a roadmap for coming developments, which have been explained to corporate providers and investors seeking new profit opportunities but have not yet been debated openly with the electorate in the UK.
\end{abstract}

KEY WORDS: health maintenance organisations, HMOs, 'liberating the NHS', NHS reform, privatisation

\section{What is the goal of the Health and Social Care Bill?}

The health white paper published in July $2010,{ }^{1-3}$ and the ministerial statements that accompanied it, presented a simple and, to many, appealing vision: the NHS performs poorly and must be reformed to improve health outcomes and save money. Yet critics rapidly undermined this vision, noting the large body of evidence that shows that the NHS is performing well in international comparisons of both health outcomes and cost-effectiveness, ${ }^{4-7}$ with substantial gains in the past decade ${ }^{8}$ and public satisfaction at an all-time high. ${ }^{9}$ They also argued that, contrary to the coalition government's pledges, the reforms advance privatisation of NHS service delivery, ${ }^{10-14}$ facilitating the emergence of a state-funded healthcare market that will welcome for-profit corporate providers.

Inevitably, people are confused, especially those who have struggled with the impenetrable text of the bill, while others, many of whom have suffered 'reform fatigue', assume that this will be just another NHS reorganisation little different from its predecessors. The amendments introduced following the 'listening pause' make no substantive changes but have augmented the confusion. ${ }^{15,16}$

Lucy Reynolds, research fellow, and Martin McKee, professor of European public health

London School of Hygiene and Tropical Medicine, 15-17 Tavistock Place, London WC1H
We argue that a clear narrative does underlie the bill, but that it is very different from that advanced by ministers. It can be traced back to the mid 1980s and the search for ways to increase private sector opportunities in healthcare provision in the UK.

An important background context is the evolution of not-forprofit health organisations in the USA. In the 1970s, American investors took over many of the non-profit health maintenance organisations (HMOs) that had, since 1929, been created to provide medical care for communities and workforces in the USA. ${ }^{17}$ By the mid-1990s, the health insurance market in the USA was saturated, with little scope for further growth. ${ }^{18}$ Its investors started to look elsewhere for profitable opportunities and identified Latin America, where healthcare was paid for from social security funds, which presented an attractive target for investors. ${ }^{19}$ As Latin America's high sovereign debt became increasingly unaffordable following a rise in interest rates in the late 1970s, creditors were able to force the opening of the public sector to international investors through a large-scale privatisation programme ('structural adjustment') of all public sector services. ${ }^{20}$ By the late 1990s, managed care was established through much of the continent, albeit against some resistance. ${ }^{21}$

\section{What of the healthcare market in the UK?}

The NHS in the UK, funded from general taxation and directly managed by government, offered little in the way of investment opportunities in the 1980s. The scope for growth in the indigenous independent sector was very limited because of the high quality of the national system. New ideas were needed to open gaps through which corporations could enter. The arguments were the same as those used to support structural adjustment in developing countries, propagating a narrative of intrinsically inefficient state provision (while downplaying its strengths) and extolling the virtues of operating public services through a market (neglecting to mention the substantial literature on market failure in health care ${ }^{21}$ and, especially, the cost of paying a substantial return to investors).

One can thus discern a sustained assault upon the values and organisation of the NHS in the UK, which has gradually laid down the framework within which a market could operate. Small reform by small reform, it has moved us toward thinking in terms of an ill-fitting consumer model of healthcare and away from the original paradigm of a communal pooling of resources to provide care according to medical need. Because of strong public support for the NHS, this transition has been slow and has been masked by concurrent changes that partially addressed some of the system's weaknesses, such as inflexibility and weak 
management information. After a quarter of a century of opening to the market, only around 5\% of the NHS's budget for secondary care is spent on private provision ${ }^{22}$ and forays into primary care provision, although subsidised, have so far largely failed.

We are now reaching the point when that oyster will finally be opened wide by the current reforms, which will bring fundamental changes in our healthcare provision, ${ }^{23,24}$ by which the introduction of private sector competition throughout both primary and secondary care will be funded on equal terms with existing NHS public sector organisations. Investors will be able to achieve their goal of direct and large-scale access to tax funding and, as Tim Evans, chief negotiator for the now defunct Independent Healthcare Association, stated: 'The NHS would simply be a kitemark attached to the institutions and activities of a system of purely private providers'. ${ }^{10}$

It is now possible to see how we came to reach this point thanks to the work of a small but dedicated group of health professionals and academics, such as those contributing to the 'Keep our NHS public' campaign ${ }^{25}$ and others who have been exchanging information on social media. ${ }^{26}$ They have subjected the current bill to the scrutiny that parliament, so far, has failed to undertake (although at the time of writing there is still hope that this may happen in the House of Lords). We now summarise what has emerged.

The ideas for the opening of the NHS to the market drew heavily on a 1985 paper by a Stanford professor, Alain Enthoven. ${ }^{27} \mathrm{He}$ was at the time consulting for Kaiser Permanente, which operates a non-profit HMO according to the 'managed care' model. This model was designed to control the tendency for medical services in the USA to profiteer at the expense of patients and their insurers. As profit-making companies are paid 'fee for service', the more tests and treatments they provide, the more money they receive, and so an HMO uses primary care doctors to monitor provision of referrals and limit their cost and quantity. Enthoven was asked to comment on the problems he perceived in the NHS and on the applicability of Kaiser's model. His commentary praised the NHS and accurately identified some of its weaknesses, before explaining how HMOs worked and why they were needed in the context of a market-based healthcare system whose costs had become unacceptably high. Enthoven later stated that: 'If privatization means turning NHS hospitals into private forprofit entities, that certainly was not my intent...the internal market model could work with no private sector at all' ${ }^{28}$ However, others took a different position. Two years later, a conference attended by Conservative politicians, NHS senior managers and think-tank advisors set out a seven-step plan to alter the NHS, ${ }^{29}$ which has been slow in coming to fruition but remarkably persistent (Box 1).

In 1988, the pro-market Centre for Policy Studies (CPS) published a series of short studies exploring this agenda (although step 6 vanished as inexpedient, as reflected in Tim Evans' comment cited above). One study was published as a pamphlet entitled Britain's biggest enterprise by Conservative members of par-

\section{Box 1. Seven-step plan to dismantle the NHS. Source: Iliffe, $1994 .^{27}$}

1 Establish the NHS as an independent statutory body with decentralised financial accountability

2 Bring the NHS and private medical care together in an integrated and inter-related market

3 Extend direct charging in a costed service

4 Devolve all responsibility for patients' care to directly funded district health authorities, dismantling regional health authorities and their planning function, with individual hospitals encouraged to opt out and compete for patients

5 End national wage bargaining for NHS staff

6 Retitle the NHS to reflect the new business era

7 Create a national health insurance scheme jointly with private insurance companies

liament (MPs) Oliver Letwin and John Redwood. ${ }^{30}$ Around this time, both of these MPs headed NM Rothschild bank's international privatisation unit, ${ }^{31}$ and in 1988 Oliver Letwin published a book Privatising the world: a study of international privatisation in theory and in practice, with a foreword by John Redwood. ${ }^{32}$

Letwin and Redwood summarised and tried to justify the 1987 plan, ${ }^{30}$ starting by identifying their perceived failings of the NHS. These were not concerned with poor health outcomes; in fact, outcomes were not mentioned at all. Instead, Letwin and Redwood identified the 'minimum' components of reform, as follows:

- $\quad$ NHS to be established as an independent trust (or trusts)

- increased use of joint ventures between the NHS and the private sector

- 'extending the principle of charging', starting with a system of 'health credits' to be combined with a contributory national health insurance scheme based on personal health budgets.

The pamphlet's final statement comments on the political feasibility of the reform:

A system of this sort would be fraught with transitional difficulties. And it would be foolhardy to move so far from the present one in a single leap. But need there be just one leap? Might it not, rather, be possible to work slowly from the present system toward a national insurance scheme?

One could begin, for example, with the establishment of the NHS as an independent trust, with increased joint ventures between the NHS and the private sector; move on next to use of 'credits' to meet standard charges set by a central NHS funding administration for independently managed hospitals or districts; and only at the last stage create a national health insurance scheme separate from the tax system.

In a subsequent CPS pamphlet also published in $1988,{ }^{33}$ Redwood proposed that groups of GPs could act as HMOs, purchasing services from capitation fees received. Another pamphlet, coauthored by MP David Willetts, suggested importing 
the American model of competing HMOs into the NHS. ${ }^{34} \mathrm{~A}$ series of documents over the subsequent 20 years echoed the same themes as preparations were put in place that would allow the Lansley reform to 'liberate' the whole system.

The first change made according to the 1985 Enthoven commentary and the 1987-8 plan was the introduction of competitive tendering for catering, cleaning and laundry services. Then, following the 1989 white paper, an internal market was created within the NHS, with a split between purchasing entities and the providers from which they commissioned care - a cumbersome and unnecessary arrangement. During the early 1990s, the GP-HMO idea was trialled through a series of schemes, including GP fundholding and 'total purchasing pilots.' ${ }^{24}$ The little evaluation of the 15 different attempts at such decentralisation did not find clear advantages or disadvantages. ${ }^{35}$ One evaluation-for-money assessment found lower patient satisfaction with fundholding GP practices and at an extra annual cost of $£ 2.68$ per head ${ }^{36}$ - a less than persuasive argument for the imminent scale up of this idea as 'clinical commissioning groups'.

The private sector was allowed to harvest an income stream from NHS capital financing from the 1990s through the private finance initiative ${ }^{37}$ - a device used to keep debt off the government balance sheet and therefore to lower the political cost of government borrowing. The year 2003 saw the first spin-off of NHS hospitals into semi-independent status as foundation trusts - a reform that the Health and Social Care Act will impose upon all NHS hospitals. At the same time, the NHS economic regulator Monitor was created, which is henceforth to enforce the competitive market for the NHS. In 2003, the private sector was allowed a privileged route to establish a foothold in small-scale elective care via the new 'independent sector treatment centres' (ISTCs), which were paid from the NHS budget but at a premium $11 \%$ higher than NHS rates, with guaranteed minimum payments and no obligation to accept difficult cases or undertake training. Evaluation was problematic in England, because the ISTCs produced very poor-quality data and the financial arrangements were commercially confidential, but it is known that they took full opportunity to select only the easiest cases. ${ }^{38}$ Data made available by one Scottish ISTC revealed that it undertook less than half the work it was paid for and what it did was heavily skewed to the most minor cases. ${ }^{39}$ Most ISTCs have since been decommissioned, often incurring exit costs. A new GP contract that allowed corporate provision of GP services was created in 2004, thus preparing the ground for the involvement of HMOs in primary care in the UK, ${ }^{10}$ and the EU-accredited 'any willing provider' procurement arrangements were introduced in 2008 , paving the way for a competitive market in primary care. ${ }^{40}$

In 2007, a set of private sector providers was identified to support commissioning by primary care trusts (PCTs). This created a group of management consultancies, accounting firms and health insurance companies that are now already experienced in supporting NHS commissioning so they can offer to support the new commissioning consortia that find their task more technical and time consuming than they were led to believe by the Department of Health. The department sought to persuade GPs that this would give them greater autonomy, glossing over the not inconsiderable risks and difficulties involved. ${ }^{41}$

By the 2010 election, it was clear that a series of gradual privatisation initiatives had failed to gain as much ground in curative care as their proponents had perhaps hoped, with a small but growing share of the market supplied through PCT commissioning going to non-public sector service suppliers. For the key private sector interest area of elective surgery, for example, this had risen to $4.3 \%$ for $2009-10$ compared with $2.8 \%$ in 2006 , according to Department of Health figures. ${ }^{42}$ To complete the 'liberalisation' plan for the NHS, a much more radical solution was needed, whereby public sector provision would simply be abolished over time. This involves:

- all NHS hospitals becoming independent foundation trusts with no guaranteed central funding

- private hospitals being allowed to compete to sell whichever procedures they wish to offer, with no requirement to contribute to the costs of medical training, services in remote areas, emergency services, highly specialised procedures or management of difficult cases

- GPs being forced into clinical commissioning groups on the HMO model

- the NHS logo being available to all of the above organisations to make it hard for patients to distinguish between them

- the limited NHS budget being forced to cover all of the extra costs involved in having a competitive market, including redundant capacity, extra administration enabling individual billing, marketing to attract patients and profittaking by investors.

The reform has been presented by the coalition as 'not a privatisation'. Although Letwin, in his book, defined privatisation as follows: ${ }^{43}$

It typically takes one of three forms: contracting out of government, deregulation of activities previously dominated by the public sector, and sales of public assets to existent private sector companies... these are important and powerful tools, each of which is particularly suited to the privatisation of a particular aspect of the public sector: contracting out for public services, deregulation for statutory monopolies, and trade sales for companies in poor financial condition.

Clearly this definition encompasses many aspects of the current reforms, which have been presented to the electorate as aiming only to empower patients and GPs and to save money through some unspecified means.

In a 2010 briefing to private equity investors in the USA, Mark Britnell, previously director-general for commissioning for the NHS and currently the partner in charge of KMPG's work with the healthcare industry, was much more frank: ${ }^{4}$ 
In [the] future, the NHS will be a state insurance provider not a state deliverer. In [the] future 'any willing provider' from the private sector will be able to sell goods and services to the system. The NHS will be shown no mercy and the best time to take advantage of this will be in the next couple of years.

Equally frank was another government health spokesman: the minister for health in the House of Lords. At a conference that covered 'Income generation - new markets for the NHS and the private sector', Earl Howe assured the attendees of 'big opportunities for the private sector here' for both corporate providers and those hoping to sell commissioning support services to clinical commissioning groups. ${ }^{45}$

\section{The next stage: health insurance to pay for NHS services}

The conservative think-tank Reform has, according to the British Medical Journal, been funded by at least three of the prospective entrants to the new English healthcare regime (General Healthcare Group (GHG), KPMG and McKinsey). ${ }^{46}$ Reform's 2008 paper on the NHS sets out a plan for conversion of the NHS to an insurance-based system with personal top-up payments. This plan is alluded to in the 2010 white paper in the opaque phrase 'money will follow the patient'. This refers to the impending roll-out of personal health budgets for all those registered with the NHS. These have been greeted with enthusiasm by patient groups, somewhat strangely when one considers that the NHS currently undertakes to cover all costs of care, whereas the concept of a finite budget implies that it is possible that the actual costs of care could exceed that budget, leaving the patient to cover the excess.

\section{Conclusion}

Enthoven's description of the HMO model, which he explicitly stated was at least as problematic but more expensive than the NHS, has somehow been adopted as a blueprint for the privatisation of the NHS. ${ }^{47}$ It was recently reported that the newer 'accountable care model' ${ }^{48}$ now finds favour with the secretary of state for health. ${ }^{49}$ This flexible model is a successor to the HMO model, although it is not greatly different in concept or operation. ${ }^{50}$ It involves a managed care arrangement in which the private sector primary care gatekeeper receives a subsidy from the government to pay all or part of the individual premiums due for the people registered with it, ${ }^{51}$ with the individuals concerned expected to pay any shortfall between the personal budgets provided by government and the amount charged by the accountable care organisation.

Fulfilment of the longstanding ambition, documented by Redwood and Letwin, to expand private financing of the healthcare system through user contributions is thus now imminent. Enthoven's reasoned view that market-based healthcare provision is more expensive and less universal than the NHS system consistently has been overlooked. His warning that managed care organisations should be non-profit has also been ignored in the UK's policy built upon his work. His comment that the socialised NHS was 'the democratic choice of the overwhelming majority of the British people' has also not prevented what we perceive as a subsequent systematic attempt to replace it covertly with a market-based system. With the passage of the Health and Social Care Act, the corporate sector will finally prise open the NHS oyster.

\section{References}

1 Equity and excellence: Liberating the NHS. White Paper. Department of Health. 12 July 2010 http://www.dh.gov.uk/en/Publicationsandstatistics/ Publications/PublicationsPolicyAndGuidance/DH_117353.

2 Equity and excellence: Liberating the NHS. Press release http://www.dh.gov.uk/en/MediaCentre/Pressreleases/DH_117360.

3 Andrew Lansley We're delivering on the NHS. Conservatives TV. http://www.conservatives.com/Video/Conservatives_TV.aspx?id=59e1 9bf4-84cf-443b-af39-90e3fd645990.

4 Helm T. Andrew Lansley accused of burying poll showing record satisfaction with NHS: Ministers are said to be withholding survey results that undermine health secretary's case for urgent radical reforms. Guardian 2011; Mar 19.

www.guardian.co.uk/society/2011/mar/19/nhs-andrew-lansley-healthcare-reform [Accessed 31 January 2012].

5 Davis K, Schoen C, Stremikis K. Mirror, mirror on the wall: how the performance of the US health care system compares internationally. 2010 update. New York: Commonwealth Fund, 2010.

6 Pritchard C, Wallace MS. Comparing the USA, UK and 17 Western countries' efficiency and effectiveness in reducing mortality. JRSM Short Rep 2011;2:60.

7 Appleby J. Does poor health justify NHS reform? BMJ 2011;342:d566.

8 Desai M, Nolte E, Karanikolos M, Khoshaba B, McKee M. Measuring NHS performance 1990-2009 using amenable mortality: interpret with care. J R Soc Med 2011;104:370-9.

9 Appleby J, Robertson R. Chapter 4. A healthy improvement? Satisfaction with the NHS under labour. In: British social attitudes 27th report. London: National Centre for Social Research, 2010. www.natcen.ac.uk/media/606952/nat\%20british\%20social\%20attitudes\%20survey\%20summary\%204.pdf [Accessed 31 January 2012].

10 Leys C, Player S. The plot against the NHS. Pontypool: Merlin Press, 2011.

11 Pollock AM, Price D. How the secretary of state for health proposes to abolish the NHS in England. BMJ 2011;342:d1695.

12 Peedell C. Further privatisation is inevitable under the proposed NHS reforms. BMJ 2011;342:d2996.

13 Reynolds L. For-profit companies will strip NHS assets under proposed reforms. BMJ 2011;342:d3760.

14 Reynolds L, McKee M. 'Any qualified provider' in NHS reforms: but who will qualify? Lancet 2011;Aug 9:doi:10.1016/S0140-6736(11)61264-6.

15 Wintour P, Boseley S. Labour ridicules David Cameron's NHS structure: Conservatives' NHS reforms would leave managers and doctors bewildered as to where responsibility lies, claims Labour. Guardian 2011;Aug 5. www.guardian.co.uk/politics/2011/aug/05/labourridicules-cameron-nhs-structure\# [Accessed 31 January 2012].

16 Reynolds L, Scott-Samuel A, McKee M. The NHS reforms and the impact of the amended Health and Social Care Bill. HSJ 2011;Sep 22. www.hsj.co.uk/why-the-amended-health-bill-still-creates-a-worryingoutlook-for-the-nhs/5034648.article [Accessed 31 January 2012].

17 Pollock AM, Leys C, Price D. NHS plc: the privatisation of our health care. London: Verso, 2005.

18 Pollock AM, Price D. Rewriting the regulations: how the World Trade Organisation could accelerate privatisation in health-care systems. Lancet 2000;356:1995-2000.

19 Stocker K, Waitzkin, Iriart C. The exportation of managed care to Latin America. N Engl J Med 1999;340:1141-36. 
20 Klein N. The shock doctrine: the rise of disaster capitalism. London: Penguin, 2008.

21 Arrow KJ. Uncertainty and the welfare economics of medical care. Am Econ Rev 1963;53:941-73.

22 Timmins N. Open market is still the stumbling block. Financial Times 2011;May 9. www.ft.com/cms/s/0/16b0285c-7a71-11e0-af6400144feabdc0,dwp_uuid=debe9554-8da0-11df-b5e200144feab49a.html\#axzz1XCStGnt5 [Accessed 31 January 2012].

23 Monbiot G. A death foretold. Monbiot.com, 2011. www.monbiot.com/2011/05/16/a-death-foretold/ [Accessed 31 January 2012].

24 Timmins N. How Lansley got into his messy revolution. Financial Times 2011;Apr 15. www.ft.com/cms/s/0/0e8c275c-678e-11e0-913800144feab49a,dwp_uuid=debe9554-8da0-11df-b5e200144feab49a.html\#axzz1XCStGnt5 [Accessed 31 January 2012].

25 Keep our NHS public. Policy briefings: our answer to market reforms. www.keepournhspublic.com/policybriefings.php [Accessed 31 January 2012].

26 McKee M, Cole K, Hurst L, Aldridge RW, Horton R. The other Twitter revolution. BMJ 2011;342:415.

27 Enthoven AC. Reflections on the management of the National Health Service: an American looks at incentives to efficiency in health services management in the UK. London: Nuffield Provincial Hospitals Trust, 1985.

28 Enthoven AC. Internal market reform of the British National Health Service. Health Aff (Millwood) 1991;10:60-70.

29 Illiffe S. Trends in Europe health care - implications for Britain's NHS. In: Ilffe S, ed. Health care and the common market proceedings the International Association for Health Policy (Eusp) comper 1993. London: LAHP Medical World, 1994:13-5.

30 Letwin O, Redwood J. Britain's biggest enterprise: ideas for radical reform of the NHS. London: Centre for Policy Studies, 1988. www.scribd.com/doc/56986348/Britain-s-Biggest-Enterprise [Accessed 31 January 2012].

31 Oborne P. 'Letwin intellectual', The Spectator, 24 November 2001; p.18.

32 Letwin O. Privatising the world: a study of international privatization in theory and practice. London: Cassell Educational, 1988:63-73.

33 Redwood J. In sickness and in health: managing change in the NHS. London: Centre for Policy Studies, 1988.

34 Goldsmith M, Willetts D. Managed health care: a new system for a better health service. London: Centre for Policy Studies, 1988.

35 Mays N, Mulligan JA, Goodwin N. The British quasi-market in health care: a balance sheet of the evidence. J Health Serv Res Policy 2000;5:49-58.

36 Dusheiko M, Gravelle M, Yu N et al. The impact of budgets for gatekeeping physicians on patient satisfaction: evidence from fund-holding. Technical paper No. 30. York: Centre for Health Economics, 2004.

37 Pollock AM, Price D, Liebe M. Private finance initiatives during NHS austerity. BMJ 2011;342:doi:10.1136/bmj.d324.

38 Browne J, Jamieson L, Lewsey J et al. Case-mix \& patients' reports of outcome in independent sector treatment centres: comparison with NHS providers. BMC Health Serv Res 2008;8:78.
39 Pollock AM, Kirkwood G. Independent sector treatment centres: the first independent evaluation, a Scottish case study. J R Soc Med 2009;102:278-86.

40 McNulty S. The nuts and bolts of the any willing provider model. Pulse 2009;Jul 15. www.pulsetoday.co.uk/pcarticle-content//article_display_list/11009619/the-nuts-and-bolts-of-the-any-willingprovider-model [Accessed 31 January 2012].

41 Reynolds L, McKee M. GP commissioning and the NHS reforms: what lies behind the hard sell? J R Soc Med 2012;105:7-10.

42 Department of Health. Question by Frank Dobson to secretary of state for health Simon Burns. Hansard 2011; Jun 13: col 650. www.publications.parliament.uk/pa/cm201011/cmhansrd/cm110613/text/11061 3w0004.htm [Accessed 31 January 2012].

43 Letwin O. Bringing about the Phenomenon, in Privatising the World: a study of international privatisation in theory and practice. London: Cassell, 1988. p74

44 Apax Partners. Opportunities post global healthcare reforms: Apax Global Healthcare Services conference, October 2010. www.powerbase.info/images/f/fe/Apax_Healthcare_conference_2010.pdf [Accessed 31 January 2012].

45 Davie E. 'Big opportunities' for private sector in health bill, says minister. Pulse 2011;Sep 7. www.pulsetoday.co.uk/newsarticle-content//article_display_list/12663018/big-opportunities-for-private-sector-inhealth-bill-says-minister [Accessed 31 January 2012].

46 Cassidy J. Lobby watch: reform. BMJ 2011;342:doi:10.1136/bmj.d2917.

47 Klein R. Markets, politicians, and the NHS: Enthoven's analysis still illuminates the NHS. BMJ 1999;319:1383.

48 Gold J. Accountable care organizations, explained. National Public Radio 2011;Jan 18. www.npr.org/2011/04/01/132937232/accountablecare-organizations-explained [Accessed 31 January 2012].

49 Lansley A. Perspectives on health care reform in the UK. Speech at Brookings Institute, Washington DC, 9 November 2011. London: Department of Health, 2011. http://mediacentre.dh.gov.uk/2011/11/09/speech-9-november2011-andrew-lansley-brookings-institute-washington-dc/ [Accessed 31 January 2012].

50 Sullivan K. The history and definition of the 'accountable care organization' Berkeley, CA: Physicians for a National Health Program, 2010. http://pnhpcalifornia.org/2010/10/the-history-and-definition-of-the$\%$ E2\% $80 \% 9$ Caccountable-care-organization\%E2\%80\%9D/ [Accessed 31 January 2012].

51 Crook C. Alain Enthoven on Ryan's Medicare plan. Atlantic 2011;Jun 3. www.theatlantic.com/national/archive/2011/06/alain-enthovenon-ryans-medicare-plan/239873/ [Accessed 31 January 2012].

Address for correspondence: Dr Lucy Reynolds, London School of Hygiene and Tropical Medicine, 15-17 Tavistock Place, London WC1H 9SH. Email: Lucy.Reynolds@Ishtm.ac.uk 